\title{
Response of Sugarcane to Fertilizers on an Organic Soil
}

\author{
F. González-Vélez and G. Samuels ${ }^{1}$
}

INTRODUC'TION

Of the about 2,165,000 acres of land in Puerto Rico about 28,000 (8) ${ }^{2}$ are considered organic soils. These organic soils, i.e. with an organic-matter content above 15 percent, constitute less than 2 percent of the $1,663,000$ acres of land available for farming. The majority of the organic soils are untilled because of very poor natural drainage, complicated sometimes by the presence of harmful salts in the profile. When properly drained and managed these peats and muck lands can rank among the most productive soils of the Island (8).

One arca of organic soil now being reclaimed is that of Caño Tiburones at Arecibo. This land-reclamation project under the sponsorship of the Land Authority of Puerto Rico has made available so far approximately 6,000 acres of a Tiburones muck for agricultural use (4). The Land Authority began growing sugarcane on this reclaimed land but sugar yields were not satisfactory, despite the applications of high rates of a 14-4-10 fertilizer used with success on mineral sugarcane soils near this area.

The Agronomy and Horticulture Depurtment of this Agricultural Experiment Station, in cooperation with the Land Authority of Puerto Rico, initiated a study to determine whether soil fertility was limiting the yields of sugarcane at Caño Tiburones. This paper deals with the response of the sugarcane to fertilizers at Caño Tiburones for a plant cane and two ratoons.

\section{THE AREA AND SITE}

Caño Tiburones occupies a narrow strip along the north-central coast of Puerto Rico between Arecibo and Barceloneta about 10 miles long and with a varying width of up to a mile, making up an area of about 6,600 acres. It is bounded on the east and west by the Manatí and Arecibo rivers, respectively.

This area once was one of the largest swamps in Puerto Rico and during heavy rains the whole area remained under water for days. The area is now surrounded by canals and pumping stations; automatic tidal gates prevent sea water from entering the canals during high tides. The pumping station has four turbines each with a capacity of 80,000 gallons per minute.

${ }^{1}$ Research Agronomist, and Agronomist, respectively, Agricultural Experiment Station, University of Puerto Rico, Río Piedras, P.R.

${ }^{2}$ Italic numbers in parentheses refer to Literature Cited, pp. 295-6. 
After the drainage operation had been at work for some time, and the soil had dried out somewhat, roads and bridges were constructed. The drainage project was started early in 1949 and the first 100 acres were planted in July 1954. A total of 3,368 acres was cultivated in the 1960-61 crop.

The site chosen for the experiment is about 100 feet from one of the main canals and borders a service road. The land is level and deep drainage ditches on each side of the experiment run into the canal. Surrounding the experimental site are commercial sugarcane fields planted at approximately the same time as the experiment.

\section{THE SOIL}

The experiment was planted on a Tiburones muck which is the most important of the poorly drained organic soils of the coastal lowlands of Puerto Rico. Tiburones muck constitutes the majority of the soil present in the Caño Tiburones area with some small amounts of Saladar muck and peat.

All the soils in this group, if not drained and cultivated, are covered with water most of the year. The most noticeable types of vegetation are mangroves, ferns, sedges, grass, and cattails.

Even when drained the soil is spongy and not very firm. Tractors when working in this soil have bars about 2 feet in length welded to the tracts to widen them to prevent them sinking into the muck. However, a person can walk on the muck without danger of sinking in above the ankles.

When dry, drained, and cultivated, the surface of the Tiburones muck to a depth of 10 inches is nearly black, granular, loose-mealy, more or less mineralized, acid, friable muck, but, when wet it is black, plastic, sticky muck. This surface layer is underlain by black stringy fibrous tule peat consisting of partly decomposed stems and fibers. It is slightly acid in reaction and salty. The material in this layer continues below a depth of 6 feet.

The Tiburones muck at the experimental site had a pH 4.9, 41 percent of organic matter, 1.65 percent of nitrogen, and 2 pounds $\mathrm{P}_{2} \mathrm{O}_{5}$ per acre as available phosphorus.

\section{PROCEDURE}

A sugarcane-fertilizer experiment was planted at Caño Tiburones, Arecibo, on July 23, 1957, on a Tiburones muck. The experiment consisted of growing sugarcane variety P.R. 980 at various levels of nitrogen, phosphorus, and potassium. A plant crop of 16 months and two 12-month ratoons were harvested from the experiment.

A randomized-block experimental design replicated six times was used 
to prove three different levels of nitrogen, phosphorus, and potassium fertilizers. The various fertilizer treatments used are given in table 1. The fertilizer for each treatment was compounded from ammonium sulfate (20-percent $\mathrm{N}$ ), superphosphate (20-percent $\mathrm{P}_{2} \mathrm{O}_{5}$ ), and potassium chloride (60-percent $\mathrm{K}_{2} \mathrm{O}$ ). The mixed fertilizer was applied to each plot once for

TABLE 1.-The yields in tons of cane per acre produced by P.R. 980, when grown at different fertilizer levels on a Tiburones muck

at Caño Tiburones, 1957-61

\begin{tabular}{|c|c|c|c|c|c|c|}
\hline \multicolumn{3}{|c|}{ Treatment per acre of- } & \multicolumn{3}{|c|}{ Yield of cane per acre for- } & \multirow{2}{*}{ Mean of all 3 crops } \\
\hline $\mathbf{N}$ & $\mathrm{P}_{3} \mathrm{O}_{6}$ & $\mathrm{~K}_{2} \mathrm{O}$ & Plant crop & First ratoon & $\begin{array}{l}\text { Second } \\
\text { ratoon }\end{array}$ & \\
\hline \multicolumn{7}{|c|}{ Nitrogen $(N)$} \\
\hline $\begin{array}{r}L b . \\
0 \\
150 \\
300\end{array}$ & $\begin{array}{c}L b . \\
300 \\
300 \\
300\end{array}$ & $\begin{array}{c}L b . \\
300 \\
300 \\
300\end{array}$ & $\begin{array}{c}r . \\
91.0 \\
84.7 \\
92.0\end{array}$ & $\begin{array}{c}T . \\
57.6 \\
59.8 \\
53.0\end{array}$ & $\begin{array}{c}T . \\
62.4 \\
60.7 \\
62.6\end{array}$ & $\begin{array}{c}T . \\
70.3 \\
68.4 \\
69.2\end{array}$ \\
\hline \multicolumn{7}{|c|}{ Phosphorus $\left(\mathrm{P}_{2} \mathrm{O}_{5}\right)$} \\
\hline $\begin{array}{l}300 \\
300 \\
300\end{array}$ & $\begin{array}{r}0 \\
150 \\
300\end{array}$ & $\begin{array}{l}300 \\
300 \\
300\end{array}$ & $\begin{array}{l}33.6 \\
89.0 \\
92.0\end{array}$ & $\begin{array}{l}24.9 \\
62.0 \\
53.0\end{array}$ & $\begin{array}{l}27.2 \\
59.9 \\
62.6\end{array}$ & $\begin{array}{l}28.6 \\
70.3 \\
69.2\end{array}$ \\
\hline \multicolumn{7}{|c|}{ Potassium $\left(K_{2} O\right)$} \\
\hline $\begin{array}{l}300 \\
300 \\
300\end{array}$ & $\begin{array}{l}300 \\
300 \\
300\end{array}$ & $\begin{array}{r}0 \\
150 \\
300\end{array}$ & $\begin{array}{l}70.6 \\
78.7 \\
92.0\end{array}$ & $\begin{array}{l}41.2 \\
49.2 \\
53.0\end{array}$ & $\begin{array}{l}43.7 \\
55.3 \\
62.6\end{array}$ & $\begin{array}{l}51.8 \\
61.1 \\
69.2\end{array}$ \\
\hline \multicolumn{7}{|c|}{$\begin{array}{l}\text { Least significant difference } \\
\text { needed between treatments } \\
\text { of same crop at: } \\
\text { 5-percent level } \\
\text { 1-percent level }\end{array}$} \\
\hline
\end{tabular}

each crop. The fertilizer was applied to the plant crop just before planting in the furrow, and to the ratoon crop as soon after cutting as conditions would permit.

The plot size was 20 feet long and 24 feet wide, or about 1/91 of an acre. The plot consisted of 4 rows planted with 3-eye sugarcane seed pieces laid on the bottom of the furrow at 1-foot intervals, and covered with soil. This gave a rate of planting of about 7,500 seed pieces per acre. 
The cane was cut by machete. That from each plot was weighed separately in the field, using a portable crane and weighing baskets. Ten whole stalks of cane, minus the tops, werc taken at random from different stools in each plot at the time of harvest. The canes were tagged as to origin and brought to the hydraulic mill at the Agricultural Experiment Station at Río Piedras for the determination of sucrose content. All canes sampled were milled not later than 24 hours after cutting.

Leaf samples for the foliar-diagnosis studies were taken at the cane age of 3 months. Eight canes were taken at random from each plot, from which leaves 4,5 , and 6 were taken from each stalk for the nutrient determination. These leaf samples were then taken to the laboratory where the corresponding analyses were performed (10).

\section{IRESUTS}

TONS OF CANE PJR ACRE

\section{Nitrogen}

There was no significant response to nitrogen fertilizer for any of the three crops. The mean of all three crops indicated that the no-nitrogen treatment. was as good as, or better than treatments where nitrogen was applied (table 1). 'The lack of response to nitrogen fertilizers in the Tiburones muck is not surprising when we consider that this soil had a total nitrogen content of $1.6 \mathrm{j}$ perent. This means that with a bulk density of $0.87 \mathrm{gm}$./ece an acre-foot of a Cuño Tiburomes muck would contain about 39,000 pounds of nitrogen. If, saty, only 1 percent of this were available to the sugareane plant, this would mean 390 pounds of nitrogen per acre, or almost twice the amant usually applied to stugarcane for good yields. Thus it appears that the (año Tiburones muck hats a large reserve of nitrogen available for many years before nitrogen fertilizers need be applied.

\section{Phosphorus}

The response of the sugarcane to phosphate fertilizer at Caño Tiburones was outstanding. l'or' the plant crop, the use of 1.50 pounds of $\mathrm{P}_{2} \mathrm{O}_{5}$ per acre gave a yield increase of nearly isi) tons more cane per acre than that under the no-phosphate treatment (table 1). This was an increase of $1(6 i$ percent. The first and second ratoon crops also showed increases of 149 and 120 percent, respectively, when the treatment with 1:50 pounds of $\mathrm{P}_{2} \mathrm{O}_{5}$ per acre was compared with the no-phosphate treatment.

The plots which received no phosphate fertilizer had poor tillering in the stools. The sugarcane produced was thin, with short internodes, and low in height. The large differences in yields produced by phosphate ferti- 
lizer are readily seen in figure 1, where cane samples from the no-phosphate plots are compared with those from plots under 150 pounds per acre of phosphate.

Despite the large tonnage increases made from the use of $1: 50$ pounds $\mathrm{P}_{2} \mathrm{O}_{5}$ per acre, the use of 300 pounds $\mathrm{P}_{2} \mathrm{O}_{5}$ per acre did not give any significantly greater increases in cane tonnage over the treatment with 150 pounds $\mathrm{P}_{2} \mathrm{O}_{5}$ per acre (table 1 ). This indicates that rates of about 150

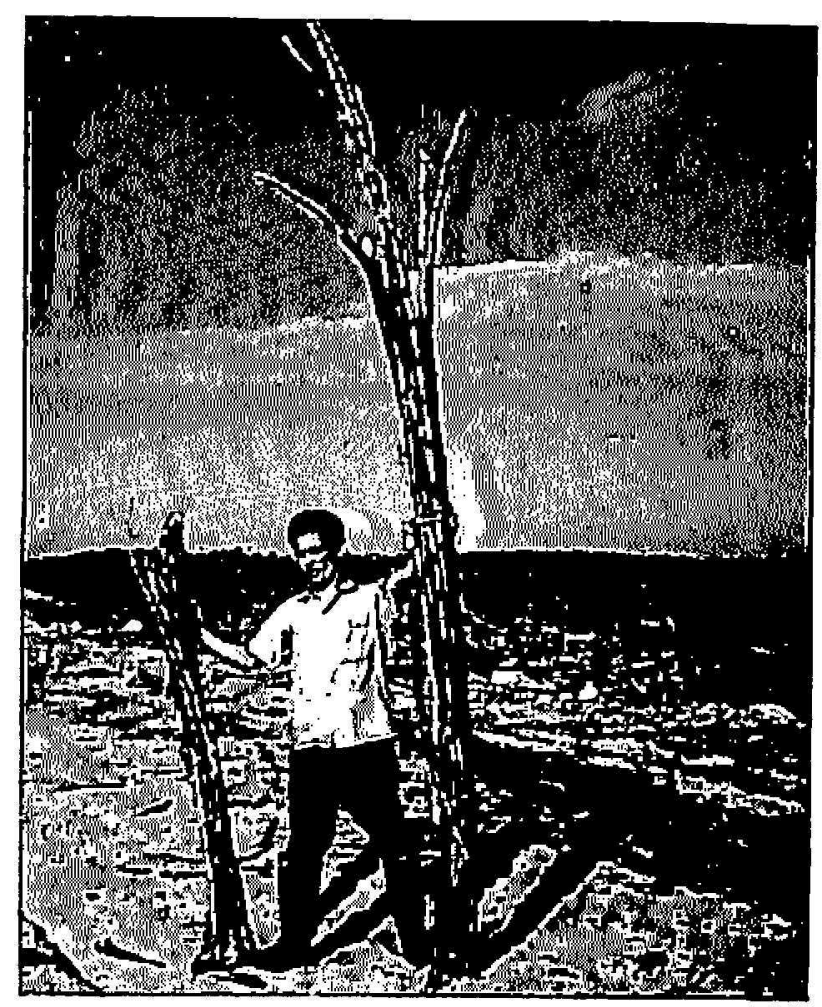

Fic. 1.-Cane samples from the plant crop of the fertilizer experiment on a Tiburones muck showing the great response to phosphate fertilizers. The cane sample on the left was from the no-phosphate treatment; the sample on the right was from the plot receiving 150 pounds of $P_{2}()_{5}$ per acere.

pounds of $\mathrm{P}_{2} \mathrm{O}_{5}$ per acre were adequate for optimum yields of cane for a Tiburones muck.

The response of sugarcane to phosphate fertilizers on a Tiburones muck resulted from a lack of a vailable phosphorus to the cane plant for growth. Analyses ${ }^{3}$ of the soil from the no-phosphate plots revealed only 2 pounds of $\mathrm{P}_{2} \mathrm{O}_{5}$ per acre, Olsen method, as compared to 40 pounds of $\mathrm{P}_{2} \mathrm{O}_{5}$ per acre where phosphate was applied. Recommendations using the Olsen method of phosphorus analysis state: Below $2: 5$ pounds $\mathrm{P}_{2}\left(\mathrm{O}_{5}\right.$ per acre, a response; 25 to 50 pounds, a probable response; above : 0 pounds, a response unlikely (7).

${ }^{3}$ The anthors wish to thank Mr. William Francia Rivera, former Research Assistant in Soils, Soils Iepartment, for the allalyses of the soil samples. 
For the Tiburones muck 40 pounds of available $\mathrm{P}_{2} \mathrm{O}_{5}$ per acre by the Olsen method indicated that no further phosphate fertilizer was needed; the 2 pounds $\mathrm{P}_{2} \mathrm{O}_{5}$ per acre definitely indicated a deficiency of phosphorus in the soil.

The response of organic soils to phosphates has been noted in the literature. Kaila (5) found large increases in hay production when phosphates were applied to a peat soil in Finland.

\section{Potassium}

Cane-tonnage yields were increased significantly by application of potash fertilizers, but not with the magnitude obtained with phosphate fertilizers. For the plant crop and first ratoon, 300 pounds of $\mathrm{K}_{2} \mathrm{O}$ per acre was needed to increase yields significantly. The second ratoon showed a significant increase in yield with 150 pounds of $\mathrm{K}_{2} \mathrm{O}$ per acre (table 1 ). The average of the three crops gave an increase of 18 percent in cane tonnage per 150 pounds of $\mathrm{K}_{2} \mathrm{O}$ per acre, and 34 percent for 300 pounds of $\mathrm{K}_{2} \mathrm{O}$ per acre, as compared with the no-potash treatment.

Responses of organic soils to potash applications have been reported for sugarcane in Florida (7) and vegetables in Michigan (2).

\section{SUCROSE-PERCENT-CANE}

\section{Nitrogen}

The use of nitrogen fertilizers on the Tiburones muck decreased the sucrose content of the sugarcane significantly for the plant cane, but not in the first or second ratoon. Inasmuch as nitrogen was not needed to increase cane tonnage, the use of nitrogen fertilizers might be expected to lower the sucrose content of the sugarcane. Samuels el al. (11) found that, for Puerto Rico, nitrogen applications tended to lower sucrose-percent-cane values when there was no increase in cane tonnage due to such nitrogen application.

\section{Phosphorus}

The action of phosphate fertilizers on the sucrose content of sugarcane growing on a Tiburones muck was not clearly defined. For the plant crop, the use of phosphates significantly increased sucrose content in the cane (table 2). However, for the first and second ratoons no such increase in sucrose from applied phosphates was apparent. In fact, the second ratoon actually showed a decrease in sucrose-percent-cane as the rate of phosphate applied to the soil was increased. Samuels et al. (1) found that where increases in cane tonnage were encountered from the use of phosphates the response in sucrose-percent-cane was sometimes negative and sometimes 
positive. However, gains in sucrose-percent-cane have been reported from use of phosphate fertilizers on mineral soils $(3,12)$.

\section{Potassium}

There was an increase in sucrose-pcrcent-cane with increasing potash applications (table 2). The increase was significant for the plant crop at

TABLe 2.-Sucrose-percent-cane produced by P.R. 980 when grown at different fertilizer level on a Tiburones muck at Caño I'iburones, 1957-61

\begin{tabular}{|c|c|c|c|c|c|c|}
\hline \multicolumn{3}{|c|}{ Treatment per acre of } & \multicolumn{3}{|c|}{ Yield of sucrose-percent-canc for- } & \multirow{2}{*}{ Means of all 3 crops } \\
\hline $\mathbf{N}$ & $\mathrm{P}_{3} \mathrm{O}_{3}$ & $\mathrm{~K}=\mathrm{O}$ & Plant crop & First ratoon & $\begin{array}{l}\text { Second } \\
\text { ratoon }\end{array}$ & \\
\hline \multicolumn{7}{|c|}{ Nilrogen $(N)$} \\
\hline $\begin{array}{r}L b . \\
0 \\
150 \\
300\end{array}$ & $\begin{array}{c}L b . \\
300 \\
300 \\
300\end{array}$ & $\begin{array}{c}L b . \\
300 \\
300 \\
300\end{array}$ & $\begin{array}{c}\text { Pereent } \\
9.49 \\
9.25 \\
8.66\end{array}$ & $\begin{array}{c}\text { Percenl } \\
7.79 \\
8.75 \\
7.91\end{array}$ & $\begin{array}{c}\text { Percent } \\
10.04 \\
9.84 \\
9.36\end{array}$ & $\begin{array}{c}\text { Percenl } \\
9.11 \\
9.28 \\
8.64\end{array}$ \\
\hline \multicolumn{7}{|c|}{ Phosphorus $\left(P_{3} O_{6}\right)$} \\
\hline $\begin{array}{l}300 \\
300 \\
300\end{array}$ & $\begin{array}{r}0 \\
150 \\
300\end{array}$ & $\begin{array}{l}300 \\
300 \\
300\end{array}$ & $\begin{array}{l}8.01 \\
9.06 \\
8.66\end{array}$ & $\begin{array}{l}7.41 \\
8.14 \\
7.91\end{array}$ & $\begin{array}{r}10.12 \\
9.90 \\
9.36\end{array}$ & $\begin{array}{l}8.51 \\
9.03 \\
8.64\end{array}$ \\
\hline \multicolumn{7}{|c|}{ Potassium $\left(\mathrm{K}_{2} \mathrm{O}\right)$} \\
\hline $\begin{array}{l}300 \\
300 \\
300\end{array}$ & $\begin{array}{l}300 \\
300 \\
300\end{array}$ & $\begin{array}{r}0 \\
150 \\
300\end{array}$ & $\begin{array}{l}8.26 \\
8.58 \\
8.66\end{array}$ & $\begin{array}{l}7.34 \\
7.27 \\
7.91\end{array}$ & $\begin{array}{l}8.71 \\
9.86 \\
9.36\end{array}$ & $\begin{array}{l}8.10 \\
8.57 \\
8.64\end{array}$ \\
\hline \multicolumn{7}{|c|}{$\begin{array}{l}\text { Least significant difference } \\
\text { needed between treatments } \\
\text { at: } \\
\text { 5-percent level } \\
\text { 1-percent level }\end{array}$} \\
\hline
\end{tabular}

300 pounds $\mathrm{K}_{2} \mathrm{O}$ per acre and the second ratoon at 150 pounds $\mathrm{K}_{2} \mathrm{O}$ per acre when compared to the no-potash treatment.

\section{SUGAR PER ACRE}

\section{Nitrogen}

The production of available $96^{\circ}$ sugar per acre followed the pattern of the tons of cane and sucrose-percent-cane, in that there was no response in 
yield to nitrogen application. The means of all three crops indicated a general decrease in tons of sugar per acre as the rate of nitrogen application increased (table 3).

\section{Phosphorus}

The use of 150 pounds of $\mathrm{P}_{2} \mathrm{O}_{5}$ per acre gave significant increases in tons of sugar per acre over the no-phosphate treatment for all three crops (table

TABI.E 3.-Yields of available $96^{\circ}$ sugar produced by P.R. 980 when grown at different fertilizer levels on a Tiburones muck at Caño Tiburones, 1957-61

\begin{tabular}{|c|c|c|c|c|c|c|}
\hline \multicolumn{3}{|c|}{ Treatment per acre of- } & \multicolumn{3}{|c|}{ Yields of available $96^{\circ}$ sugar per acre for } & \multirow{2}{*}{ Means of all 3 crops } \\
\hline N & $\mathrm{P}_{2} \mathrm{O}_{5}$ & $\mathrm{~K}_{2} \mathrm{O}$ & Plant crop & First ratoon & $\begin{array}{l}\text { Second } \\
\text { ratoon }\end{array}$ & \\
\hline \multicolumn{7}{|c|}{ Nitrogen $(N)$} \\
\hline $\begin{array}{r}L b . \\
0 \\
150 \\
300\end{array}$ & $\begin{array}{c}L b . \\
300 \\
300 \\
300\end{array}$ & $\begin{array}{c}\boldsymbol{L b} . \\
300 \\
300 \\
300\end{array}$ & $\begin{array}{c}T . \\
8.64 \\
7.89 \\
7.97\end{array}$ & $\begin{array}{c}T . \\
4.60 \\
5.22 \\
4.19\end{array}$ & $\begin{array}{c}T . \\
6.26 \\
5.98 \\
5.89\end{array}$ & $\begin{array}{c}T . \\
6.50 \\
6.36 \\
6.02\end{array}$ \\
\hline \multicolumn{7}{|c|}{ Phosphorus $\left(\mathrm{P}_{2} \mathrm{O}_{5}\right)$} \\
\hline $\begin{array}{l}300 \\
300 \\
300\end{array}$ & $\begin{array}{r}0 \\
150 \\
300\end{array}$ & $\begin{array}{l}300 \\
300 \\
300\end{array}$ & $\begin{array}{l}2.69 \\
8.09 \\
7.97\end{array}$ & $\begin{array}{l}1.82 \\
5.07 \\
4.19\end{array}$ & $\begin{array}{l}2.74 \\
5.93 \\
5.89\end{array}$ & $\begin{array}{l}2.42 \\
6.36 \\
6.02\end{array}$ \\
\hline \multicolumn{7}{|c|}{ Potassium $\left(\mathrm{K}_{2} \mathrm{O}\right)$} \\
\hline $\begin{array}{l}300 \\
300 \\
300\end{array}$ & $\begin{array}{l}300 \\
300 \\
300\end{array}$ & $\begin{array}{r}0 \\
150 \\
300\end{array}$ & $\begin{array}{l}5.84 \\
6.78 \\
7.97\end{array}$ & $\begin{array}{l}3.04 \\
3.59 \\
4.19\end{array}$ & $\begin{array}{l}3.80 \\
5.47 \\
5.89\end{array}$ & $\begin{array}{l}4.23 \\
5.28 \\
6.02\end{array}$ \\
\hline \multicolumn{7}{|c|}{$\begin{array}{l}\text { Least significant difference } \\
\text { needed between treatments } \\
\text { at: } \\
\text { 5-percent level } \\
\text { 1-percent level }\end{array}$} \\
\hline
\end{tabular}

3). The increase was 5.4 tons for the plant crop and 3.2 tons for the first and second ratoon crops, giving an increase of 3.9 tons for the average of the three crops. If we allow a price of $\$ 40.55$ per ton of superphosphate (20-percent $\mathrm{P}_{2} \mathrm{O}_{5}$ ), cost of application of $\$ 1.00$ per acre, and a selling price of sugar at $\$ 120.00$ per ton, the profit realized from the 150-pound $\mathrm{P}_{2} \mathrm{O}_{5}$ per-acre treatment amounts to about $\$ 632$ for the plant crop and $\$ 368$ for a ratoon. 
There was no significant response in tons of sugar to 300 pounds of $\mathrm{P}_{2} \mathrm{O}_{5}$ per acre as compared with the treatment with 150 pounds per acre.

\section{Potassium}

The favorable influence of potash fertilizers on the cane tonnage and on the sucrose-percent-cane combined to give a significant benefit in yields of sugar per acre. Although the omission of potash did not decrease yields of sugar as markedly as for phosphates, the use of potash fertilizers did give

TABLE 4.-The nutrient content of sugarcane leaf blades and relalive yields of $96^{\circ}$ available sugar per acre for the 3 crops of P.R. 980 grown at different fertilizer levels at Caño Tiburones

\begin{tabular}{|c|c|c|c|c|c|c|c|}
\hline \multicolumn{3}{|c|}{ Treatment per acre of- } & \multicolumn{4}{|c|}{ Nutrient content of leaf blade, dry-weight basis, } & \multirow{2}{*}{$\begin{array}{l}\text { Available sugar, } \\
\text { means of all } 3 \\
\text { cropss }\end{array}$} \\
\hline $\mathbf{N}$ & $\mathrm{P}_{2} \mathrm{O}_{6}$ & $\mathrm{~K}_{2} \mathrm{O}$ & Plant crop & First ratoon & $\begin{array}{l}\text { Second } \\
\text { ratoon }\end{array}$ & $\mid \begin{array}{c}\text { Means of all } \\
3 \mathrm{crops}\end{array}$ & \\
\hline \multicolumn{8}{|c|}{ Nilrogen $(N)$} \\
\hline $\begin{array}{r}L l . \\
0 \\
150 \\
300\end{array}$ & $\begin{array}{c}L b . \\
300 \\
300 \\
300\end{array}$ & $\begin{array}{c}L b . \\
300 \\
300 \\
300\end{array}$ & $\begin{array}{c}\text { Percent } \\
1.46 \\
1.59 \\
1.76\end{array}$ & $\begin{array}{c}\text { Percent } \\
1.20 \\
1.24 \\
1.30\end{array}$ & $\begin{array}{c}\text { Percent } \\
1.30 \\
1.36 \\
1.54\end{array}$ & $\begin{array}{c}\text { Percent } \\
1.32 \\
1.40 \\
1.53\end{array}$ & $\begin{array}{c}\text { Percent } \\
108 \\
105 \\
100\end{array}$ \\
\hline \multicolumn{8}{|c|}{ Phosphorus $(P)$} \\
\hline $\begin{array}{l}300 \\
300 \\
300\end{array}$ & $\begin{array}{r}0 \\
150 \\
300\end{array}$ & $\begin{array}{l}300 \\
300 \\
300\end{array}$ & $\begin{array}{r}0.09 \\
.17 \\
.20\end{array}$ & $\begin{array}{r}0.09 \\
.17 \\
.20\end{array}$ & $\begin{array}{r}0.11 \\
.17 \\
.23\end{array}$ & $\begin{array}{r}0.10 \\
.17 \\
.21\end{array}$ & $\begin{array}{r}40 \\
108 \\
100\end{array}$ \\
\hline \multicolumn{8}{|c|}{ Potassium (K) } \\
\hline $\begin{array}{l}300 \\
300 \\
300\end{array}$ & $\begin{array}{l}300 \\
300 \\
300\end{array}$ & $\begin{array}{r}0 \\
150 \\
300\end{array}$ & $\begin{array}{l}1.39 \\
1.68 \\
1.84\end{array}$ & $\begin{array}{l}0.69 \\
1.27 \\
1.36\end{array}$ & $\begin{array}{l}0.93 \\
1.30 \\
1.84\end{array}$ & $\begin{array}{l}1.00 \\
1.42 \\
1.68\end{array}$ & $\begin{array}{r}75 \\
88 \\
100\end{array}$ \\
\hline
\end{tabular}

significant increases in tons of sugar per acre. The use of 300 pounds of $\mathrm{K}_{2} \mathrm{O}$ per acre, as compared to the no-potash treatment gave increases of 2.13 tons for the plant crop, 1.15 for the first ratoon, and 2.09 for the second ratoon (table 3), giving an increase of 1.79 tons of sugar per acre for the means of all three crops.

\section{FOLIAR DIAGNOSIS}

The nutrient content of the sugarcane leaf blades, and the relative yields of $96^{\circ}$ available sugar per acre for the means of the three crops are given in table 4. 
The yield data were converted from tons of $96^{\circ}$ available sugar to relative yields of $96^{\circ}$ available sugar per acre. The relative yield was defined for this purpose as the percentage which the actual yield of sugar was of the yield obtained with the heaviest fertilizer application.

\section{Nitrogen}

Inasmuch as there was no significant response in yields attributable to the application of nitrogen, the relationship between the leaf-nitrogen values and sugar yields was not significant. As shown in table 4, the leafnitrogen values increased with increasing rates of nitrogen fertilizer applied to the soil, but the yields of sugar per acre decreased slightly with increasing nitrogen applications.

The leaf-nitrogen value of 1.32 percent, corresponding to the nonitrogen application, was lower than the 1.50-percent leaf-nitrogen value normally associated with no response to nitrogen fertilizer applications (10). The plant cane had leaf values near or above 1.50-percent nitrogen, but the first and second ratoons had low leaf-nitrogen values. Perhaps for organic soils such as the Tiburones muck, leaf-nitrogen values of approximately 1.30 percent and above indicate sufficient soil nitrogen available for high cane yields; whereas, for mineral soils, leaf-nitrogen values of 1.50 percent and above indicate no response to nitrogen fertilizers. Further investigation is needed before this hypothesis can be fully accepted.

\section{Phosphorus}

The lowest values for leaf phosphorus ever obtained for sugarcane growing in Puerto Rico were found in this experiment on a Tiburones muck at Caño Tiburones. A mean leaf-phosphorus value of 0.10 percent, dry weight, was associated with a mean relative yield of $96^{\circ}$ available sugar of 40 percent (table 4). An earlier experiment at Isabela on a phosphate-deficient Coto clay showed a mean leaf-phosphorus value of 0.16 percent with relative sugar yields of 78 percent (6).

For the Tiburones muck, a leaf-phosphorus value of 0.17 percent was associated with no response to phosphate fertilizers. Leaf-phosphorus values of 0.18 percent or above are normally considered in Puerto Rico as indicating no response to phosphate fertilizers (10).

Leaf-phosphorus values and yields of sugar were significantly correlated. The phosphorus content of the leaf and sugar yields both rose with increasing phosphate applications (table 4). The correlation was not so good as it might have been, because the highest rate of phosphates, 300 pounds $\mathrm{P}_{2} \mathrm{O}_{5}$ per acre, failed to give any increase in yield over the 150 pounds of $\mathrm{P}_{2} \mathrm{O}_{5}$ per acre, whereas the leaf-phosphorus values did increase with the highest phosphate rate.

Despite this, the correlation between leaf phosphorus and sugar yields, 
using the arc-tangent equation of Capó (1), was significant, with a prediction value of 78 percent. The equation obtained was:

$$
Y r=9.48 \operatorname{arc}-\tan P+81.4
$$

where $Y r=$ relative yields of sugar per acre and arc-tan $P=$ the arctangent value corresponding to the percent-leaf-phosphorus.

\section{Potassium}

The relationship between leaf potassium and relative sugar yields was not highly significant, having a prediction value of only 47 percent. This was, in part, because of the low leaf-potassium values in the first ratoon, despite response to potash applications.

A mean leaf potassium value of 1 percent was associated with relative yields of sugar of 75 percent, and 1.68-percent leaf potassium was associated with a relative sugar yield of 100 percent (table 4). In general for Puerto Rico, leaf-potassium values of 1.00 to 1.40 are considered low and definite responses to potash fertilizers are expected (10). Leaf-potassium values of 1.65 percent or above are normally regarded as indicative of no response to potash fertilizers.

\section{SUMMARY}

A fertilizer experiment using sugarcane variety P.R. 980 on a Tiburones muck at Caño Tiburones was carried on for a plant cane and two ratoons. The major results were:

1. Nitrogen fertilizers gave no response in cane tonnage, sucrose-percentcane, or tons of sugar per acre.

2. There was a highly significant response to phosphate fertilizers at the rate of 150 pounds $\mathrm{P}_{2} \mathrm{O}_{6}$ per acre in cane tonnage. The use of 300 pounds $\mathrm{P}_{2} \mathrm{O}_{5}$ per acre gave no significant increase over the level of 150 pounds of $\mathrm{P}_{2} \mathrm{O}_{5}$ per acre.

3. Cane tonnage was significantly increased with the use of 300 pounds of $\mathrm{K}_{2} \mathrm{O}$ per acre, but not with 150 pounds of $\mathrm{K}_{2} \mathrm{O}$ per acre.

4. Sucrose-percent-cane responses to the fertilizers were variable, ranging from a decrease in sucrose caused by nitrogen in the plant cane to signifcant increases attributable to phosphorus for the plant cane and to potash for the plant cane and second ratoon.

5. Tons of sugar were significantly increased under 150 pounds of $\mathrm{P}_{2} \mathrm{O}_{5}$ and 300 pounds of $\mathrm{K}_{2} \mathrm{O}$ per acre.

6. Leaf-phosphorus values were significantly correlated with the relative yields of $96^{\circ}$ available sugar per acre. A leaf-phosphorus value of 0.17 percent or above was associated with no response to phosphate fertilizers.

7. Leaf-potassium values were not as significantly correlated to sugar 
yields as leaf-phosphorus. Leaf-potassium values of 1 percent was associated with relative yields of sugar of 75 percent, and the cane responded to potash applications.

\section{RESUMEN}

Se llevó a cabo un experimento con caña de azúcar de la variedad P.R. 980 en un suelo del tipo turba Tiburones en el Caño Tiburones, Arecibo. Se cosecharon una plantilla y dos retoños con los resultados siguientes:

1. La aplicación de abonos nitrogenados no aumentó el tonelaje de la caña, ni el porcentaje de sacarosa en la caña, ni el número de toneladas de caña por cuerda.

2. La caña respondió en un alto grado significativo a las aplicaciones de abonos fosfatados a razón de 150 libras de $\mathrm{P}_{2} \mathrm{O}_{5}$ por cuerda, en cuanto al tonelaje de caña. El uso de 300 libras de $\mathrm{P}_{2} \mathrm{O}_{5}$ por cuerda no indujo aumentos significativos sobre el tonelaje de caña que produjo la aplicación de 150 libras de $\mathrm{P}_{2} \mathrm{O}_{6}$ por cuerda.

3. El tonelaje de la caña aumentó significativamente mediante la aplicación de 300 libras de $\mathrm{K}_{2} \mathrm{O}$ por cuerda, pero no así con la aplicación de 150 libras de $\mathrm{K}_{2} \mathrm{O}$ por cuerda.

4. El efecto de los abonos sobre el porcentaje de sacarosa en la caña varió en forma tal que hubo un descenso en este porcentaje debido a la presencia de nitrógeno en la plantilla y un aumento significativo debido a la presencia de potasa en la plantilla y en el segundo retoño.

5. El tonelaje de azúcar aumentó significativamente mediante la aplicación de 150 libras de $\mathrm{P}_{2} \mathrm{O}_{5}$ y 300 libras de $\mathrm{K}_{2} \mathrm{O}$ por cuerda.

6. Los valores de fósforo en la hoja se correlacionaron significativamente con los rendimientos relativos de azúcar disponible a $96^{\circ}$ por cuerda. Un valor de fósforo en la hoja de 0.17 por ciento o mayor se asoció al hecho de que la caña no respondiera a la aplicación de los abonos fosfatados.

7. Los valores de potasio en la hoja no estuvieron correlacionados significativamente con los rendimientos relativos, como en el caso de los valores de fósforo en la hoja. Valores de potasio de 1.0 por ciento estuvo asociado con los rendimientos relativos de azúcar al 75 por ciento, por lo que la caña respondió a las aplicaciones de potasa.

\section{LITERATURE CITED}

1. Capó, B. G., and Samuels, G., The development of a mathematical concept to interpret the relationship between plant composition and crop yield, $J$. Agr. Univ. P.R. 37 (4) 249-64, 1953.

2. Davis, J. F., and Lucas, R. E., Organic Soils, their Formation, Distribution, Utilization, and Management, Michigan State Univ. Agr. Expt. Sta., Special Bul. 425, pp. 1-155, 1959.

3. Denison, F. C., Report of Committee in Charge of the Experiment Station, Hawaiian Sugar Planter's Association, p. 97, 1927. 
4. Hernández-Agosto, M. A., From swamps to sugarcane, Sugar J. 24 (2) 60-2, July, 1961.

5. Kaila, A., Effect on a peat of application of superphosphate at various rates, Maataloust Aikak., 31 120-30, (Univ. Helsinki); abstracted in Soils \& Fertilizers 22 (5) 2219, 1959.

6. Landrau, P., Jr., and Samuels, G., Response of four sugarcane varieties to fertilizers during the first Isabela Cycle, 1946-51, J. Agr. Univ. P.R. 38 (2) 73-95, (1954).

7. le Grand, G., Growing Sugarcane on Organic Soils for Sugar Production, Univ. Fla., Agr. Exp. Sta. Everglade Exp. Sta., Report 62-6, pp. 4, Aug. 1961.

8. Lugo-López, M. A., and Bonnet, J. A., Utilization of organic soils in Puerto Rico, J. Agr. Univ. P.R. 35 (2) 57-65, 1961.

9. Olsen, S. R., Cole, C. V., Watanabe, F. S., and Dean, L. A., Estimation of Available Phosphorus in Soils by Extraction with Sodium Bicarbonate, USDA, Circ. 939, pp. 1-19, March 1954.

10. Samuels, G., Landrau., P., Jr., Alers-Alers, S., and Riera, A., The Method of Foliar Diagnosis as Applied to Sugarcane, Univ. P.R. Agr. Expt. Sta. Bul. 123 pp. 1-47, Feb. 1955.

11. Samuels, G., Lugo-López, M. A., and Landrau, P., Jr., Factors affecting the sucrose content of sugarcane: Fertilizers, J. Agr. Univ. P.R. 36 (3) 194-202, 1952.

12. Verret, J. A., Report of Committee in Charge of the Experiment Station, Hawaiian Sugar Planter's Assoc., p. 45, 1928. 